\title{
ANALISIS POTENSI MATA AIR SEMERU UNTUK KEBUTUHAN AIR BERSIH PENDUDUK DAN IRIGASI PERTANIAN DESA NGUTER, KECAMATAN PASIRIAN, KABUPATEN LUMAJANG
}

\author{
Ikaf Fajar Maulana, Syamsul Bachri, dan Didik Taryana
}

Masuk: 01022017 / Diterima: 01042017 / Dipublikasi: 30062017

(c) 2017Fakultas Hukum dan IImu Sosial UNDIKSHA dan IGI

\begin{abstract}
This study aims to determine the water needs for residents and irrigation in Nguter Village. This study was conducted to determine the potential of Semeru spring for the fulfillment of water needs. The method used in this research is the survey covers the measurement of the quantity of springs using WEIR method, water quality measurement, population interviews, and irrigation needs are analyzed using software cropwat 8.0. The results obtained the average discharge Semeru spring water that is equal to 1.564.973,28 liter/day. In terms of quality Semeru spring included into the category worth to be supplied to residents and irrigation. The average water needs of Nguter Village residents in the dry season and the rain is 608,569.5 liters/day. In quantity comparison of Semeru spring watercourses to the needs of clean water of the population is sufficient from the present or 50 years ahead.Semeru springs meet the needs of the Umengan irrigation network.
\end{abstract}

Key words: Potential springs Water needs, Irrigation needs

\begin{abstract}
AbstrakPenelitian ini bertujuan untuk mengetahui kebutuhan air untuk penduduk dan irigasi di Desa Nguter. Selain itu, penelitian ini dilakukan untuk mengetahui potensi mata air Semeru untuk pemenuhan kebutuhan air bagi penduduk dan irigasi. Metode yang digunakan dalam penelitian ini adalah survey meliputi pengukuran kuantitas mata air dengan menggunakan metode WEIR, pengukuran kualitas air, kebutuhan air penduduk dilakukan wawancara, serta kebutuhan irigasi dianalisis menggunakan software cropwat 8.0. Berdasarkan hasil penelitian diperoleh hasil debit rata-rata mata air Semeru yaitu sebesar 1.564.973,28 liter/hari. Dari segi kualitas mata air Semeru termasuk kedalam kategori layak untuk disuplai kepada penduduk maupun irigasi. Rata-rata kebutuhan air penduduk Desa Nguter pada musim kemarau dan hujan yang $608.569,5$ liter/hari. Secara kuantitas perbandingan debit mata air Semeru untuk kebutuhan air bersih penduduk sangat mencukupi dari masa sekarang atau 50 tahun kedepan. Selain itu, mata air Semeru memenuhi kebutuhan dalam jaringan irigasi Umengan.
\end{abstract}

Kata kunci : Potensi mata air, Kebutuhan air, Kebutuhan irigasi

\section{Pendahuluan}

Peran mata air untuk masyarakat sangat penting karena berguna memenuhi kebutuhan dasar manusia dan pembangunan. Kebutuhan air bagi keperluan manusia

Ikaf Fajar Maulana, Syamsul Bachri dan Didik Taryana Jurusan Geografi, FIS UM

Malang

ikaf.fajar@gmail.com yang terus menerus harus dijaga supaya keberadaan serta keberlanjutan keadaan, sifat, dan fungsi sumberdaya air agar senantiasa tersedia dalam kuantitas dan kualitas yang memadai untuk memenuhi kebutuhan makhluk hidup seperti kebutuhan air penduduk dan irigasi baik pada waktu sekarang maupun waktu yang akan datang. Ketersediaan air bersih untuk 
kebutuhan sehari-hari dan irigasi sangat penting bagi berbagai lapisan masyarakat.Karena segala aktifitas masyarakat di berbagai aspek kehidupan manapun memerlukan air bersih.

Berdasarkan peta jaringan air bersih di Kabupaten Lumajang, saat ini terdapat \pm 28 sumber mata air yang tersebar di seluruh Kabupaten Lumajang. Jumlah air bersih yang berasal dari mata air yang tersedia di Kabupaten Lumajang hanya dapat menyuplai $7,7 \%$ dari penduduk Kabupaten Lumajang. Menurut data Kabupaten Lumajang dalam angka 2015, pemanfaatan mata air Semeru untuk ketersediaan air bersih penduduk hanya dapat menjangkau dua Kecamatan yakni Kunir dan Tempeh. Di Kecamatan Kunir, jumlah penduduk yang tersuplai air bersih sebanyak 451 keluarga dan yang belum tersuplai air bersih sebanyak 10.043 keluarga, jadi hanya $4,3 \%$ keluarga yang mendapatkan sumberdaya air dari mata air Semeru. Sedangkan di Kecamatan Tempeh, jumlah keluarga yang belum tersuplai air sebanyak 23.875 dan yang sudah tersuplai sebanyak 1.391 keluarga, jadi hanya $5,5 \%$ keluarga yang telah tersuplai air (Kabupaten Lumajang dalam Angka, 2015).

Ketersediaan air bersih oleh penduduk Desa Nguter berasal dari air tanah sedangkan seluruh lahan pertanian dengan total luas pertanian di Desa Nguter 1.043 ha masih bergantung pada Sungai musiman di Desa Nguter. Ketersediaan air bersih di Desa Nguter saat ini memanfaatkan air tanah dangkal yang pada saat musim kemarau mengalami penurunan muka air tanah, sehingga mengalami krisis air bersih. Ketersediaan air untuk sektor pertanian masyarakat di Desa Nguter memanfaatkan air sungai musiman. Sehubungan dengan hal tersebut sangat menarik untuk dikaji potensi mata air semeru, untuk memenuhi kebutuhan air di masa kemarau penduduk di Desa Nguter.

\section{Metode}

Metode yang digunakan pada penelitian ini adalah survey. Metode ini mengumpulkan beberapa data yang bertujuan untuk menganalisis potensi mata air Semeru di Desa Nguter, Kecamatan Pasirian, Kabupaten Lumajang berdasarkan segi kuantitas dan kualitasnya untuk memenuhi kebutuhan air bersih penduduk dan kebutuhan irigasi di Desa Nguter.

Data yang dikumpulkan dalam penelitian ini berupa data primer dan sekunder. Data primer meliputi debit mata air Semeru, kualitas air mata air Semeru dan jumlah kebutuhan air bersih penduduk di Desa Nguter, Kecamatan Pasirian, Kabupaten Lumajang. Sedangkan untuk data sekunder meliputi curah hujan, suhu udara rata-rata, kelembaban relatif ratarata, kecepatan angin rata-rata, penyinaran matahari rata-rata, dan monografi Desa Nguter.

Metode yang digunakan untuk menghitung debit mata air yakni weir. Pengukuran kualitas air menggunakan waterchecker dan turbidymeter. Jumlah kebutuhan air bersih diketahui dari wawancara dengan teknik pengumpulan data stratified random sampling dengan membedakan jenis pekerjaan. Sedangkan untuk menganalisis jumlah kebutuhan air untuk irigasi menggunakan software 
cropwat 8.0. Analisis dalam penelitian yakni deskriptif komparatif yakni membandingkan debit mata air Semeru dengan kebutuhan air bersih penduduk dan kebutuhan irigasi di Desa Nguter, Kecamatan Pasirian, Kabupaten Lumajang.

\section{Hasil dan Pembahasan}

Berdasarkan hasil survey yang dilakukan di mata air Semeru, maka diperoleh data hasil pengukuran meliputi kuantitas mata air Semeru. Deskripsi data disajikan dalam Tabel 1.

Tabel 1

Hasil Pengukuran Debit Mata Air Semeru Tahun 2016

\begin{tabular}{cccc}
\hline $\begin{array}{c}\text { Tanggal } \\
\text { pengukuran }\end{array}$ & $\begin{array}{c}\text { Panjang penampang } \\
\text { bendungan }(\mathrm{m})\end{array}$ & $\begin{array}{c}\text { Tinggi muka } \\
\text { air }(\mathrm{m})\end{array}$ & $\begin{array}{c}\text { Debit } \\
\left(\mathrm{m}^{3} / \mathrm{menit}\right)\end{array}$ \\
\hline $\begin{array}{c}\text { 25 Juni } \\
\text { 2016 }\end{array}$ & 12,2 & 0,083 & $1.192,469$ \\
29 Juni & 12,2 & 0,078 & $1.086,787$ \\
2016 & 12,2 & 0,081 & $1.149,881$ \\
5 Juli 2016 & 12,2 & 0,08 & $1.113,498$ \\
9 Juli 2016 & 12,2 & 0,079 & $1.107,293$ \\
13 Juli & & & \\
2016 & 12,2 & 0,079 & $1.107,293$ \\
\hline 2016 Juli & & & \\
\hline
\end{tabular}

Sumber: Pengolahan Data Primer, 2016

Tabel 2

Hasil Pengukuran Kualitas Mata Air Semeru Tahun 2016

\begin{tabular}{lcccccc}
\hline \multirow{2}{*}{ Parameter } & \multicolumn{5}{c}{ Hasil pengukuran } \\
\cline { 2 - 7 } & 25 & 29 & 5 Juli & 9 Juli & 13 & 16 \\
& Juni & Juni & & Juli \\
\hline Temperatur $\left({ }^{\circ} \mathrm{C}\right)$ & 17.5 & 18.1 & 17.8 & 18.4 & 18.6 & 18.6 \\
Kekeruhan $($ NTU) & 5 & 3 & 5 & 1 & 0 & 0 \\
Warna & Tidak & Tidak & Tidak & Tidak & Tidak & Tidak \\
Bau & Tidak & Tidak & Tidak & Tidak & Tidak & Tidak \\
Rasa & Tidak & Tidak & Tidak & Tidak & Tidak & Tidak \\
\hline \multicolumn{5}{c}{ Sumber: Pengolahan Data Primer, 2016 }
\end{tabular}

Berdasarkan Tabel 1 maka diketahui tinggi muka air terendah yaitu $0,078 \mathrm{~m}$ yang dilakukan pada 29 Juni 2016 dengan debitnya sebesar $1.086,787 \mathrm{~m}^{3} /$ menit. Adapun tinggi muka air tertinggi yang dilakukan pengukuran pada tanggal debit tertinggi yakni 25 Juni 2016 dengan tinggi muka air 0,83 $\mathrm{m}$ yang diketahui debitnya sebesar 1.192,469 $\mathrm{m}^{3} /$ menit.

Berdasarkan nilai debit yang diperoleh adalah air yang keluar pada bendungan, maka untuk mendapatkan nilai debit terendah untuk seluruh bagian penampang adalah dengan menghitung rata-rata tinggi muka air 
dari perhitungan di lapangan dan memperoleh nilai debit terendah untuk mata air sebesar $1.086,787 \mathrm{~m}^{3} /$ menit atau $1.564 .973,28 \mathrm{~m}^{3} /$ hari.

\section{Kualitas Mata Air}

Kualitas mata air diperoleh dari hasil pengukuran dan pengamatan secara langsung. Dalam penelitian ini hasil uji kualitas air didasarkan pada standar air bersih yang telah ditentukan oleh PERMENKES RI.No 416 / MENKES / PER/IX/1990 dengan parameter fisik air. Hasil pengukuran yang telah dilakukan di lapangan dapat dilihat pada tabel 2 .

Tabel 2 menunjukkan bahwa parameter fisik seperti warna, bau, dan rasa cenderung konstan yakni tidak terdapat perubahan pada setiap musimnya. Sedangkan pada parameter temperatur mata air Semeru memiliki temperatur tertinggi $18,6^{\circ} \mathrm{C}$ sedangkan temperatur terendah $17,5{ }^{\circ} \mathrm{C}$. Parameter lain yakni kekeruhan mata air Semeru memiliki skala terendah 0 NTU dan skala tertinggi yang terjadi pada musim penghujan yakni 5 NTU.

\section{Kebutuhan Air Bersih Penduduk}

Besarnya kebutuhan air bersih penduduk perhari di Desa Nguter diketahui dari hasil wawancara kepada 93 responden di Desa Nguter pada masing-masing jenis pekerjaan. Jumlah kebutuhan air bersih perhari pada berbagai jenis pekerjaan dapat dilihat pada Tabel 3

Tabel 3

Kebutuhan Air Bersih berdasarkan Jenis pekerjaan Desa Nguter Tahun 2016

\begin{tabular}{|c|c|c|c|c|c|c|}
\hline \multirow[t]{2}{*}{ No } & \multirow[t]{2}{*}{ Pekerjaan } & \multirow{2}{*}{$\begin{array}{l}\text { Jumlah } \\
\text { anggota } \\
\text { keluarga } \\
\text { responden } \\
\text { (orang) }\end{array}$} & \multicolumn{2}{|c|}{$\begin{array}{c}\text { Jumlah kebutuhan air } \\
\text { bersih responden } \\
\text { (liter) }\end{array}$} & \multicolumn{2}{|c|}{$\begin{array}{l}\text { Kebutuhan air } \\
\text { (orang/perhari) }\end{array}$} \\
\hline & & & Penghujan & Kemarau & Penghujan & Kemarau \\
\hline 1 & Petani & 83 & $5.510,1$ & $5.552,6$ & 66,4 & 66,9 \\
\hline 2 & Buruh tani & 161 & $11.283,7$ & $11.416,9$ & 70,1 & 70,9 \\
\hline 3 & Pertambangan & 6 & 411 & 417,6 & 68,5 & 69,6 \\
\hline 4 & Industri & 30 & $2.218,4$ & $2.258,1$ & 74 & 75,3 \\
\hline 5 & Konstruksi & 26 & $1.856,3$ & $1.891,7$ & 71,4 & 72,7 \\
\hline 6 & Angkutan & 10 & 685,3 & 693,4 & 68,5 & 69,3 \\
\hline 7 & Perdagangan & 63 & $4.626,9$ & $4.722,8$ & 73,4 & 74,9 \\
\hline 8 & Jasa-jasa & 26 & $1.966,7$ & $1.987,3$ & 75,6 & 76,4 \\
\hline 9 & $\begin{array}{l}\text { TNI/POLRI/PNS } \\
\text { Rata-rata }\end{array}$ & 3 & 224,9 & 225,6 & 75 & 75,2 \\
\hline 10 & $\begin{array}{l}\text { kebutuhan air } \\
\text { (liter/hari) }\end{array}$ & & & & 71,4 & 72,3 \\
\hline
\end{tabular}

Sumber: Pengolahan Data Primer, 2016

Berdasar Tabel 3, kebutuhan air bersih per jenis pekerjaan tertinggi pada jasa-jasa, TNI/POLRI/PNS dan industri. Kebutuhan air perkapita perhari terendah pada jenis pekerjaan petani.Selain jenis pekerjaan, tingkat konsumsi antara musim penghujan dan kemarau juga berbeda. Rata-rata 
kebutuhan air pada musim penghujan 71,4 liter/orang/ hari dan kebutuhan air dalam musim kemarau yakni 72,3 liter/ orang/hari.

Total kebutuhan air bersih penduduk Desa Nguter perhari diperoleh dari hasil perhitungan ratarata konsumsi air perhari pada setiap musim. Dengan jumlah penduduk Desa Nguter sebesar 8.470 jiwa diperoleh total kebutuhan air pada musim penghujan sebesar 604.758 liter/hari dan musim kemarau 612.381 liter/hari.
Kebutuhan air penduduk disetiap kategori erat sekali hubungannya dengan perkembangan dan pertambahan jumlah penduduk. Perkembangan dan pertambahan jumlah penduduk akan menentukan besarnya kebutuhan air bersih dimasa yang akan datang.

Berikut hasil perhitungan proyeksi penduduk dengan menggunakan metode aritmatik dan total kebutuhan air dari tahun 2011-2050 dapat dilihat pada Tabel 4

Tabel 4

Proyeksi Jumlah Penduduk Desa Nguter dan Kebutuhan Air Penduduk 2016-2050

\begin{tabular}{|c|c|c|c|}
\hline \multirow{2}{*}{ Tahun } & \multirow{2}{*}{$\begin{array}{l}\text { Jumlah penduduk } \\
\text { (jiwa) }\end{array}$} & \multicolumn{2}{|c|}{ Jumlah kebutuhan air (liter/hari) } \\
\hline & & Penghujan & Kemarau \\
\hline 2025 & 8.068 & $576.055,2$ & $583.316,4$ \\
\hline 2030 & 7.934 & $566.487,6$ & $573.628,2$ \\
\hline 2035 & 7.800 & 556.920 & 563.940 \\
\hline 2040 & 7.666 & $547.352,4$ & $554.251,8$ \\
\hline 2045 & 7.532 & $537.784,8$ & $544.563,6$ \\
\hline 2050 & 7.398 & $528.217,2$ & $534.875,4$ \\
\hline
\end{tabular}

Sumber: Pengolahan Data Primer, 2016

Tabel 4 menunjukkan jumlah penduduk Desa Nguter dari tahun 2025-2050 mengalami penurunan sebesar 0,024 atau $2,4 \%$. Penurunan jumlah penduduk memengaruhi jumlah kebutuhan air penduduk.Dari tabel di atas kebutuhan air setiap 5 tahun kedepan selalu mengalami penurunan seiring penurunan jumlah penduduk Desa Nguter dari tahun ketahun. Pada musim penghujan penurunan kebutuhan air selama 5 tahun kedepan sebesar 9567,6 liter/hari, sedangkan musim kemarau penurunan sebesar 9.688,2 liter/hari.

\section{Kebutuhan Irigasi}

Berdasarkan hasil pengukuran yang telah dilakukan menggunakan software cropwat 8.0 maka dapat dijabarkan berdasarkan beberapa faktor berikut ini antara lain:

a. Evapotranspirasi potensial (ETo)

Evapotranspirasi potensial (ETo) bulanan dihitung tiap tahun dalam 10 tahun terakhir (2006-2015) untuk mengetahui perbedaan nilai kebutuhan air dari tahun 2006-2015. Dilakukan juga pengukuran untuk mengetahui ketinggian tempat (Altitude) di Desa Nguter yaitu 49 meter di atas permukaan laut, garis lintang (Latitude) $8^{\circ} 50$ LS, dan garis bujur (Longitude) $113^{\circ} 20 \mathrm{BT}$.

Berikut hasil pengukuran evapotranspirasi potensial (ETo) menggunakan Cropwat 8.8seperti terlihat pada Gambar 1. 


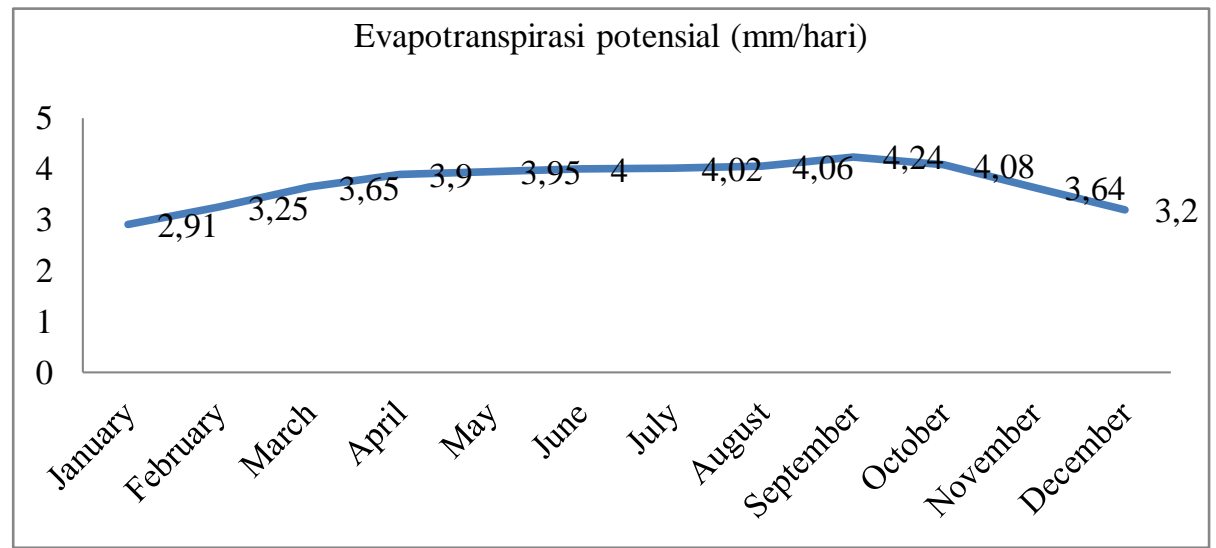

Gambar 1

Rata-rata Evapotranspirasi Potensial (ETo)Bulanan Desa Nguter Tahun 2006-2015

Gambar 1 menunjukkan grafik rata-rata evapotranspirasi potensial (ETo) tertinggi terjadi pada musim kemarau yang meliputi bulan Juni sampai Oktober yakni sebesar 4 sampai 4,24 $\mathrm{mm} /$ hari. Sedangkan ratarata evapotranspirasi potensial (ETo) pada musim penghujan tergolong lebih rendah dibandingkan dengan musim kemarau yakni sebesar 2,9 sampai 3,9 $\mathrm{mm} /$ hari.

\section{b. Curah hujan efektif}

Hujan efektif merupakan curah hujan yang dapat dimanfaatkan oleh tanaman untuk irigasi.Dalam perhitungan curah hujan efektif, data yang digunakan adalah data rata-rata sepuluh tahun dari tahun 2006 sampai 2016.Berikut ini hasil perhitungan hujan efektif yang terjadi di Desa Nguter dapat dilihat pada Gambar 2.

\section{Gambar 2 Curah Hujan Efektif 70\% Tanaman Padi Desa Nguter Tahun 2006-2015}

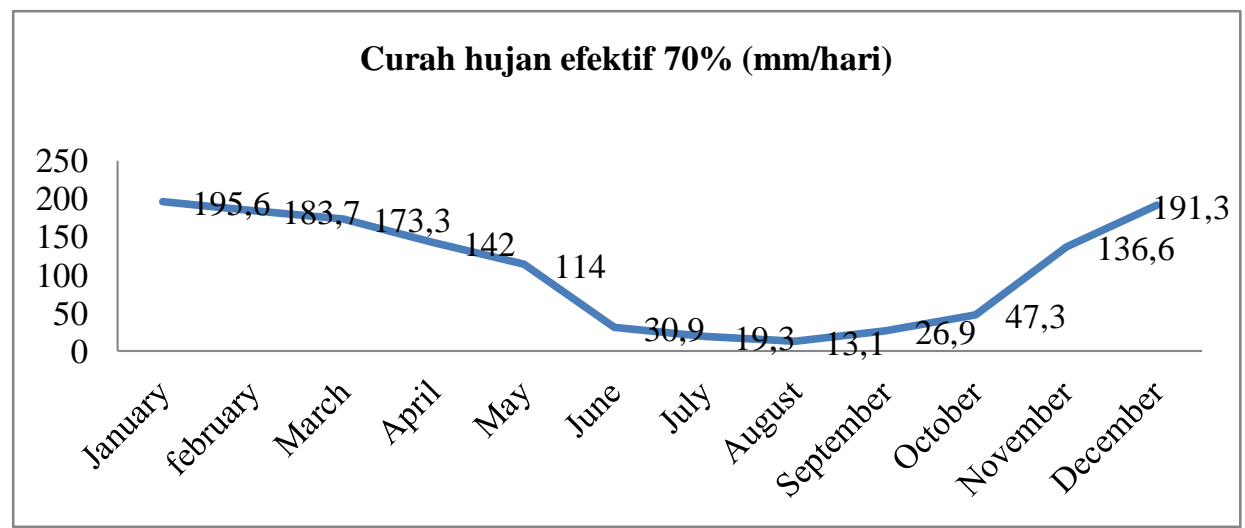

Berdasarkan Gambar 2 curah hujan efektif tanaman padi di Desa Nguter dapat diketahui pada bulan Januari terjadi curah hujan efektif yang cukup tinggi yaitu 195,6 mm/hari, sedangkan pada bulan September terjadi curah hujan efektif yang kecil yaitu $13,1 \mathrm{~mm} /$ hari. Sedangkan curah hujan efektif untuk tanaman palawija seperti sebesar dengan 50\%.dapat dilihat pada Gambar 3. 


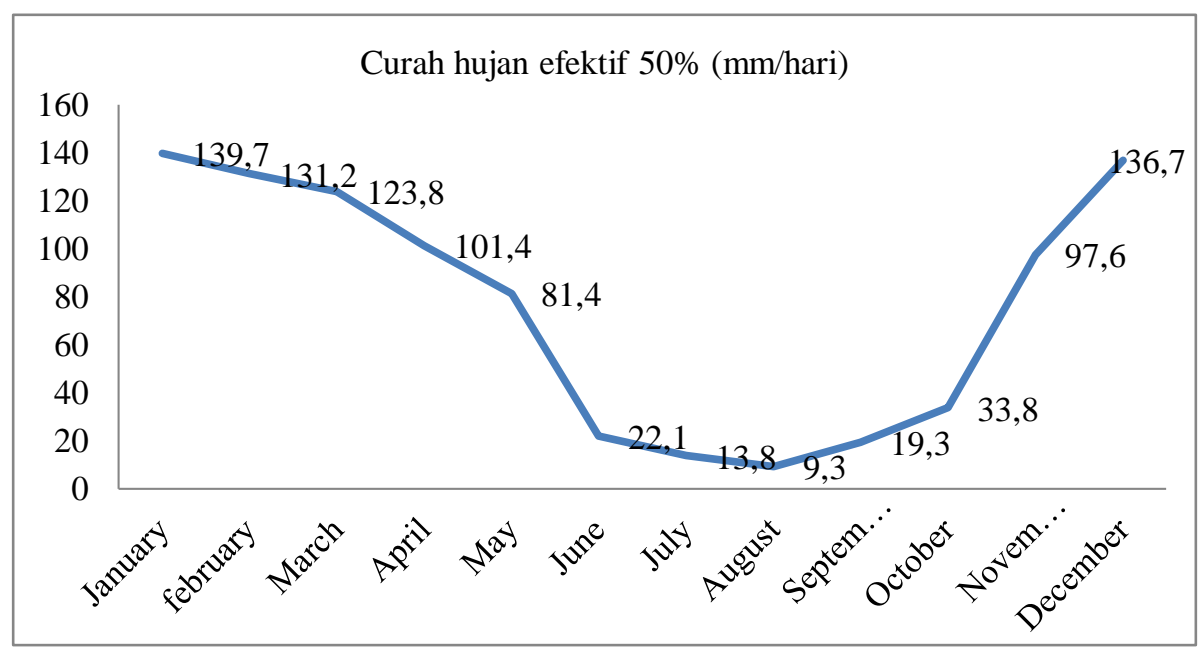

Gambar 3

Curah Hujan Efektif 50\% Tanaman Jagung Desa Nguter Tahun 2006-2015

Berdasarkan Gambar 3 bulan musim penghujan curah hujan menunjukkan adanya pergeseran diatas $\pm 100 \mathrm{~mm}$ perbulan.

musim di Desa Nguter terlihat pada c. Tanah

saat bulan-bulan musim kemarau Dari hasil analisa secara teknis di tepatnya pada bulan Juni sampai laboratorium dan pengamatan secara Oktober curah hujan efektif dibawah langsung di lapangan maka diperoleh $\pm 30 \mathrm{~mm}$ perbulan.Memasuki bulandata sifat fisik dilokasi pengamatan seperti pada tabel di bawah ini.

Tabel 5

Sifat Fisik Tanah Desa Nguter Tahun 2016

\begin{tabular}{|c|c|c|c|c|c|}
\hline \multirow{2}{*}{ No } & \multirow{2}{*}{ Lokasi } & \multicolumn{3}{|c|}{ Fraksi (\%) } & \multirow{2}{*}{$\begin{array}{c}\text { Klas } \\
\text { tekstur }\end{array}$} \\
\hline & & Pasir & Debu & Liat & \\
\hline 1 & Titik I & 39 & 40 & 21 & Lempung \\
\hline 2 & Titik II & 43 & 42 & 15 & Lempung \\
\hline
\end{tabular}

Berdasarkan tabel di atas dapat dilihat bahwasanya dari kedua lokasi pengambilan sampel di Desa Nguter bertekstur lempung.Pada titik I komposisi fraksi pasir 39\%, debu $40 \%$, dan liat $21 \%$.Sedangkan pada titik II komposisi fraksi pasir $43 \%$, debu $42 \%$, dan liat $15 \%$.

Tekstur tanah sangat mempengaruhi tingkat resapan air kedalam tanah.Perbedaan tekstur tanah menyebabkan tingkat peresapan air dan menyimpan air yang berbeda pula.Kebutuhan air untuk irigasi ditentukan oleh jumlah air yang masuk ke dalam tanah.Berikut merupakan hasil infiltrasi yang akan disajikan dalam Tabel 6. 
Tabel 6

Hasil Laju Infiltrasi dan Perkolasi Desa Nguter tahun 2016

\begin{tabular}{ccc}
\hline No & Lokasi & Infiltrasi $(\mathrm{mm} / \mathrm{jam})$ \\
\hline 1 & Titik I & $15,8 \mathrm{~mm} / \mathrm{jam}$ \\
2 & Titik II & $3,9 \mathrm{~mm} / \mathrm{jam}$
\end{tabular}

Sumber: Pengolahan Data Primer, 2016

Berdasarkan Tabel 6 dapat dilihat lokasi I mempunyai nilai infiltrasi paling tinggi yaitu sebesar 15,8 $\mathrm{mm} / \mathrm{jam}$ dan lokasi II mempunyai nilai infiltrasi paling kecil yaitu sebesar $3,9 \mathrm{~mm} / \mathrm{jam}$.

d. Pola Tanam

Data tanaman pada Desa Nguter dapat dihitung kebutuhan air irigasi, dengan menambahkan tanggal tanam, maka kebutuhan air irigasi untuk tanaman dalam satu tahun dapat ditentukan. Kebutuhan air selama penyiapan lahan maka data yang diperlukan yakni infiltrasi pada penyiapan lahan sebesar $3,9 \mathrm{~mm} / \mathrm{hari}$, dan evaporasi saat penyiapan lahan sebesar $4,08 \quad \mathrm{~mm} / \mathrm{hari}$, jangka waktupenyiapan lahan, dan kebutuhan air untuk penjenuhan. Dari hasil perhitungan kebutuhan air untuk penyiapan lahan, satuan lahan dengan luas 1 ha membutuhkan 12,94 $\mathrm{mm} /$ hari/ha, jika dilakukan konversi maka $(1 \mathrm{~mm} /$ hari/ha $=0,11574 \mathrm{lt} /$ detik /ha) maka kebutuhan air saat penyiapan lahan sebesar 1,5 liter/detik/ha.

Setelah kebutuhan air untuk penyiapan lahan maka kebutuhan air tanaman dihitung pada setiap tahapan pada setiap tanaman.Berikut ini hasil analisis kebutuhan untuk tanaman pada setiap masa tanam I di Desa Nguter seperti terlihat pada Tabel 7.

Tabel 7

Kebutuhan Air Tanaman pada Masa Tanam I Tanaman Padi Desa Nguter Tahun 2016

\begin{tabular}{ccccc}
\hline Bulan & Dekade & Tahap & $\begin{array}{c}\text { Kebutuhan air konsumtif (ETc) } \\
\mathrm{mm} / \text { hari }\end{array}$ & $\begin{array}{c}\text { Hujan efektif } \\
\mathrm{mm} / \text { hari }\end{array}$ \\
\hline Nov & 1 & Init & 4,06 & 3,83 \\
Nov & 2 & Init & 4 & 4,73 \\
Nov & 3 & Deve & 3,84 & 4,85 \\
Dec & 1 & Deve & 3,71 & 4,93 \\
Dec & 2 & Deve & 3,59 & 5,16 \\
Dec & 3 & Mid & 3,52 & 5,14 \\
Jan & 1 & Mid & 3,42 & 5,09 \\
Jan & 2 & Mid & 3,31 & 5,1 \\
Jan & 3 & Mid & 3,44 & 5,08 \\
Feb & 1 & Late & 3,56 & 5,06 \\
Feb & 2 & Late & 3,55 & 5,04 \\
Feb & 3 & Late & 3,55 & 5,02 \\
Mar & 1 & Late & 3,56 & 4,03 \\
Total & & & 47,11 & 63,06 \\
\hline
\end{tabular}

Sumber: Pengolahan Data Primer, 2016 
Tabel 7 menunjukan pada November dekade I dimulai dari tahap permulaan rata-rata kebutuhan air konsumtif (ETc) 4,03 mm/hari. Setelah itu, tanaman padi masuk ke tahap perkembangan tanaman padi kebutuhan konsumtif (ETc) lebih kecil dibandingkan tahap permulaan dengan rata-rata kebutuhannya $3,71 \mathrm{~mm} /$ hari. Memasuki tahap pertengahan kebutuhan air konsumtif (ETc) mengalami penurunan dari tahap sebelumnya yakni $0,29 \mathrm{~mm} /$ hari atau memiliki rata-rata kebutuhan air konsumtif (ETc) 3,42 mm/hari. Setelah melalui tahap pertengahan tanaman padi memasuki tahap akhir dengan rata-rata kebutuhan air konsumtif (ETc) sebesar $3,55 \mathrm{~mm} /$ hari.

Berikut ini hasil analisis kebutuhan irigasi pada setiap MT II dan MT III dapat dilihat pada Tabel 8 .

Tabel 8

Kebutuhan Air Tanaman pada Masa Tanam II Tanaman Jagung Desa Nguter Tahun 2016

\begin{tabular}{ccccc}
\hline Bulan & Dekade & Tahap & $\begin{array}{c}\text { Kebutuhan air } \\
\text { konsumtif (ETc) } \\
\mathrm{mm} / \text { hari }\end{array}$ & Hujan efektif \\
$\mathrm{mm} / \mathrm{hari}$
\end{tabular}

Sumber: Pengolahan Data Primer, 2016

Tabel 9

Kebutuhan Air Tanaman Masa Tanam III Tanaman Jagung Desa Nguter Tahun 2016

\begin{tabular}{ccccc}
\hline Bulan & Dekade & Tahap & $\begin{array}{c}\text { Kebutuhan air } \\
\text { konsumtif (ETc) } \\
\text { mm/hari }\end{array}$ & Hujan efektif \\
mm/hari
\end{tabular}

Sumber: Pengolahan Data Primer, 2016 
Tabel 8 menunjukan tahap permulaan rata-rata kebutuhan air konsumtif (ETc) sebesar 1,88 mm/hari. Pada tahap perkembangan tanaman jagung membutuhkan rata-rata kebutuhan air konsumtif (ETc) sebesar 2,97 $\mathrm{mm} /$ hari. Tahap pertengahan tanaman jagung membutuhkan ratarata kebutuhan air konsumtif (ETc) untuk pertumbuhannya $3,965 \mathrm{~mm} /$ hari. Setelah melalui beberapa tahap maka tanaman jagung memasuki tahap akhir dengan membutuhkan air untuk kebutuhan konsumtif dengan rata-rata $3,38 \mathrm{~mm} /$ hari.

Tabel 9 bahwa tahap permulaan rata-rata kebutuhan air konsumtif (ETc) sebesar 2,015 mm/hari. Pada tahap perkembangan tanaman jagung membutuhkan rata-rata kebutuhan air konsumtif (ETc) sebesar 2,76 mm/hari. Tahap pertengahan tanaman jagung membutuhkan rata-rata kebutuhan air konsumtif (ETc) untuk pertumbuhannya 4,15 $\mathrm{mm} /$ hari. Setelah melalui beberapa tahap maka tanaman jagung memasuki tahap akhir dengan membutuhkan air untuk kebutuhan konsumtif dengan rata-rata 3,58 $\mathrm{mm} /$ hari.

\section{Analisis Potensi Mata Air Semeru untuk Kebutuhan Penduduk dan Irigasi}

Total kebutuhan air bersih penduduk perhari diperoleh dari hasil perhitungan antara kebutuhan air masing-masing penduduk dengan jumlah penduduk Desa Nguter, maka diperoleh total kebutuhan Desa Nguter sebesar 604.758 liter/hari. Dibawah ini hasil perbandingan antara debit mata air Semeru dengan kebutuhan air bersih penduduk sebagai berikut.
- $Q$ mata air = 1.645.977,6 liter/hari

- $Q$ penduduk $=604.758$ liter/hari

- Q mata air > Q penduduk

Selain dilakukan perbandingan antara kuantitas mata air Semeru pada musim penghujan dengan kebutuhan air bersih penduduk Desa Nguter, perlu juga dilakukan perbandingan antara kuantitas mata air Semeru pada musim kemarau dengan kebutuhan air bersih penduduk Desa Nguter. Diketahui bahwa debit mata air Semeru pada musim kemarau sebesar 1.597.478,4 liter/hari. Hasil perbandingannya sebagai berikut.

- $Q$ mata air $=1.597 .478,4$ liter/hari

- $Q$ penduduk $=612.381$ liter/hari

- Q mata air > Q penduduk

Berdasarkan hasil perbandingan di atas maka kuantitas mata air Semeru pada musim penghujan dan musim kemarau atau ketersediaan mata air Semeru sangatlah mencukupi untuk kebutuhan air bersih seluruh Desa Nguter. Kebutuhan air penduduk erat sekali hubungannya dengan perkembangan dan pertambahan jumlah penduduk untuk penyediaan air. Perkembangan dan pertambahan jumlah penduduk akan menentukan besarnya kebutuhan air bersih dimasa yang akan datang.

Perbandingan antara kuantitas mata air Semeru dengan kebutuhan air bersih penduduk dilakukan untuk menganalisis potensi mata air Semeru di Desa Nguter dalam memenuhi kebutuhan air bersih penduduk selama 50 tahun kedepan maka mata air Semeru masih dapat memenuhi 
kebutuhan konsumtif air bersih penduduk Desa Nguter.

Berdasarkan hasil perbandingan antara kuantitas mata air Semeru dengan kebutuhan air penduduk yang sangatlah mencukupi untuk kebutuhan air bersih seluruh Desa Nguter, maka dilakukan analisis potensi kuantitas mata air Semeru untuk kebutuhan irigasi. Berikut hasil perbandingan antara debit mata air Semeru dengan kebutuhan total pada setiap jaringan irigasi Desa Nguter.

- $Q$ mata air $=1.013 .158,5$ liter/hari

- $\quad$ mata air $<$ Q Irigasi Mukini

- Q mata air $<$ Q Irigasi Lobang 1

- $\quad$ mata air $<Q$ Irigasi Poteh

- $Q$ mata air $>Q$ Irigasi Umengan

Perbandingan antara kuantitas mata air Semeru dengan kebutuhan irigasi pertanian dilakukan untuk menganalisis potensi mata air Semeru di Desa Nguter dalam memenuhi kebutuhan irigasi dalam satu tahun. Dari hasil perbandingan tersebut diketahui bahwa hanya jaringan irigasi Umengan yang kuantitas mata airnya mencukupi kebutuhan air irigasi.

\section{Pembahasan}

\section{Analisis Kualitas Air untuk Kebutuhan Penduduk dan Irigasi}

Analisis kualitas mata air Semeru dilakukan untuk melihat kesesuaian air untuk kebutuhan penduduk dan irigasi Desa Nguter. Hasil pengukuran yang dilakukan setiap parameter seperti warna, bau, dan rasa sama sekali tidak terindikasi pada mata air Semeru. Selain itu, parameter fisik lain seperti temperatur tertinggi benilai $18,6^{\circ} \mathrm{C}$ dan terendah $17,5^{\circ} \mathrm{C}$. Parameter lain yakni kekeruhan memiliki skala terendah 1 NTU dan skala tertinggi yang terjadi pada musim penghujan yakni 5 NTU.

Perubahan kualitas air pada setiap parameter, seperti kekeruhan, disebabkan oleh adanya bahan organik dan anorganik yang tersuspensi dan terlarut (Efendi, 2003: 60). Tingkat kekeruhan mata air Semeru sangat rendah dan tidak terdapat perbedaan yang signifikan antara pada musim penghujan dan musim kemarau. Meskipun tingkat kekeruhan pada musim kemarau lebih rendah dibandingkan penghujan, pada musim kemarau lebih terlihat jernih dan cahaya matahari menembus sampai dasar perairan.Sedangkan pada musim penghujan terdapat sedikit zat yang tersuspensi di dalam perairan meskipun tidak pada intensitas yang tinggi.

Temperatur dipengaruhi kondisi musim, pada musim hujan temperatur air lebih rendah dibandingkan musim kemarau. Hal ini disebabkan hujan yang menurunkan temperatur udara dan menaikkan kelembaban udara. Bila dibandingkkan dengan musim kemarau dengan lama penyinaran lebih panjang dibandingkan musim penghujan, maka lama penyinaran akan menaikkan suhu udara dan suhu pada badan mata air Semeru.

Warna ditimbulkan oleh adanya bahan organik dan bahan anorganik (Efendi, 2003: 61).Kondisi yang seperti ini mengindikasikan bahwa tidak ada bahan-bahan organik seperti plankton, humus, dan algae. Selain itu, mata air Semeru masih belum tercemar bahanbahan kimia yang dapat merubah warna dari perairan mata air Semeru. 
Parameter lain seperti bau dan rasa pada kondisi air mata air Semeru tidak terindikasi terjadinya pencemaran dari aktivitas manusia. Tidak ada aktivitas industri di dekat mata air Semeru, selain itu lokasi antara pemukiman dan mata air Semeru terletak sekitar $\pm 2 \mathrm{~km}$, jadi tidak ada kontak secara langsung dengan aktivitas manusia. Menurut Widyastuti, dkk (2014: 165) pada dasarnya faktor yang berpengaruh terhadap kondisi kualitas air di suatu daerah adalah faktor alami dan faktor buatan.

Berdasarkan standar dari PERMENKES RI.No 416/ MENKES/PER/ IX/1990 sebuah mata pada setiap parameter harus memenuhi standar yang telah ditentukan. Dalam penelitian ini menunjukan bahwa mata air Semeru dapat dinyatakan sebagai air bersih dan sesuai untuk memenuhi kebutuhan penduduk dan irigasi dari segi kualitasnya.

\section{Analisis Kuantitas Mata Air}

Analisis potensi kuantitas mata air Semeru dilakukan untuk mengetahui besarnya ketersediaan air bersih yang dihasilkan. Jumlah debit mata air Semeru pada musim penghujan 1.143,04 liter/menit dan pada musim kemarau sebesar 1.109,36 liter/menit.

Besar kecilnya debit mata air dipengaruhi oleh iklim, topografi, karakteristik akuifer, dan struktur geologi (Tolman dalam Wardani, 2010:2). Dari hasil pengukuran debit pada setiap musimnya tidak terdapat penurunan debit secara signifikan. Perubahan debit mata air dipengaruhi oleh kondisi iklim, antara musim kemarau dan penghujan memiliki perbedaan debit mata air Semeru. Pada musim penghujan curah hujan lebih tinggidibandingkan musim kemarau, sehingga menyebabkan musim penghujan debit mata air lebih tinggi.Hal ini disebabkan oleh suplai pada daerah tangkapan hujan (recharge area) untuk mengisi air tanah lebih besar dibandingkan musim kemarau.

Mata air Semeru muncul kepermukaan tanah dikarenakan perubahan topografi yang mengalami penurunan dan memotong akuifer bebas (unconfined aquifer). Biasanya wilayah morfologi kaki gunung api, banyak di temukan sumber mata air yang relatif besar berupa titik mata air (spring) karena secara hidromorfologi wilayah ini merupakan jalur mata air (spring belt).

Debit mata air Semeru berasal dari daerah tangkapan tepatnya diatas wilayah Desa Nguter yakni kawasan Pronojiwo dan Candipuro yang memiliki karakteristik akuifer terbuka yang menyebabkan pengaliran air hujan ke zona akuifer bebas tepatnya di daerah Pasirian. Berdasarkan proses terjadinya, maka mata air Semeru tergolong tipe depression spring yakni akuifer bebas (unconfined aquifer) yang mengalami kenaikan ke permukaan (Fetter dalam Kodoatie, 2012:84).

\section{Kebutuhan Air Bersih Penduduk}

Total kebutuhan air bersih penduduk perhari diperoleh dari hasil perhitungan antara kebutuhan air masing-masing penduduk dengan jumlah penduduk Desa Nguter. Diperoleh total kebutuhan Desa Nguter musim penghujan dan kemarau 
sebesar 604.758 liter/hari dan 612.381 liter/hari.

Berdasarkan proyeksi jumlah penduduk Desa Nguter dari tahun 2016-2050, total penduduk yang menetap di Desa Nguter selalu mengalami penurunan. Penurunan ini sebesar 2,4\% dari total penduduk di Desa Nguter. Hal ini dikarenakan tingkat mortalitas dari tahun ketahun lebih besar dibandingkan natalitas.Berdasarkan paparan data diatas maka dapat disimpulkan bahwasanya setiap 5 tahun terakhir kebutuhan air untuk konsumsi penduduk dan penduduk mengalami penurunan sebesar 9.628 liter/hari dan 134 jiwa.

Kebutuhan air penduduk dipengaruhi oleh beberapa faktor seperti karakteristik penduduk, ukuran kota, dan kondisi iklim (Linsley, 1995: 233). Berdasarkan karakteristik penduduk Desa Nguter, kondisi sosial ekonomi mempengaruhi tinggi rendahnya kebutuhan air.Faktor yang menyebabkan perbedaan jumlah konsumsi pada setiap profesi dipengaruhi oleh jumlah konsumsi kendaraan pribadi.Menurut Usman dalam Widayanti (2014: 23) kebutuhan air lebih besar bagi penduduk dengan kondisi sosial-ekonomi yang lebih baik.

Ukuran kota juga menjadi faktor yang memengaruhi jumlah kebutuhan air penduduk. Berdasarkan rata-rata kebutuhan air perkapita perhari yakni selama musim penghujan dan kemarau sebesar 71,8liter/hari. Desa Nguter masuk ke dalam kategori $\mathrm{V}$ (desa dengan rata-rata jumlah penduduk $<20.000$ jiwa).

Tingkat penggunaan air penduduk dipengaruhi pula oleh kondisi iklim disuatu daerah.Menurut Linsley (1995: 233) penduduk di daerah panas membutuhkan air lebih banyak daripada penduduk di daerah dingin atau pada saat musim kemarau kebutuhan air menjadi lebih banyak dibandingkan pada saat musim hujan.

Berdasarkan rata-rata konsumsi di Desa Nguter pada musim penghujan dan kemarau memiliki perbedaan.Perbedaan penggunaan air pada musim kemarau dan penghujan disebabkan oleh pola penggunaan untuk memasak dikarenakan pada musim kemarau membutuhkan jumlah air untuk konsumsi yang lebih banyak dibandingkan penghujan.

\section{Kebutuhan Irigasi}

Kebutuhan air irigasi ditentukan oleh beberapa faktor seperti evapotranspirasi, curah hujan efektif, tanaman (tipe tanaman dan umur tanaman), tekstur tanah (Suyono dan Darmakusuma, 1991: 27). Evapotranspirasi potensial (ETo) berbeda setiap bulannya hal ini tergantung kepada besarnya suhu ratarata bulanan, kelembaban udara bulanan, kecepatan angin bulanan, dan lama penyinaran bulanan. Evapotranspirasi yang terjadi di Desa Nguter dalam satu tahun memiliki ratarata $3,74 \mathrm{~mm} /$ hari. Evapotranspirasi yang tertinggi terjadi pada bulan September yakni 4,24 $\mathrm{mm} /$ hari sedangkan yang terendah terjadi pada bulan Januari sebesar 2,91 $\mathrm{mm} /$ hari. Evapotranspirasi musim kemarau lebih tinggi dibandingkan musim penghujan, hal ini disebabkan oleh keadaan meteorologi yang berbeda pada setiap musimnya.Pada musim kemarau penyinaran matahari lebih intensif 
dibandingkan dengan musim penghujan. Intensitas penyinaran matahari yang tinggi dan suhu yang tinggi akan menyebabkan kebutuhan air untuk evapotranspirasi meningkat. Sebaliknya, kelembaban udara yang tinggi, suhu yang rendah, dan intensitas penyinaran matahari yang rendah akan menyebabkan kebutuhan air untuk evapotranspirasi lebih rendah.

Curah hujan juga menjadi faktor yang dapat menentukan jumlah kebutuhan air irigasi. Curah hujan yang terjadi di Desa Nguter sebesar 1820,1 $\mathrm{mm} /$ tahun. Curah hujan yang tertinggi terjadi pada bulan November sampai April dengan intensitas rata-rata 243 $\mathrm{mm} /$ bulan.Untuk musim kemarau Desa Nguter memiliki intensitas curah hujan yang rendah yakni sebesar 59 $\mathrm{mm} /$ bulan.Curah hujan yang terjadi di suatu daerah bermanfaat sebagai suplai untuk kebutuhan pertanian.

Perbedaan tekstur juga menjadi faktor yang memengaruhi jumlah kebutuhan air irigasi.Banyaknya kebutuhan air yang digunakan untuk irigasi tidak semuanya digunakan oleh tanaman namun banyak yang diserap oleh tanah. Kondisi fisik tanah di Desa Nguter bertekstur lempung dengan laju infiltrasi $15,8 \mathrm{~mm} / \mathrm{jam}$ dan nilai infiltrasi tekstur lempung sebesar 12,5-25 $\mathrm{mm} / \mathrm{jam}$ (kriteria cepat). Cepatnya laju infiltrasi pada kondisi tekstur tanah berlempung di Desa Nguter dapat ditentukan oleh komposisi fraksi.

Kebutuhan air untuk irigasi pertanian harus mempertimbangkan tipe tanaman dan umur tanaman (tingkat pertumbuhan) (Fatchan dkk, 1990: 50).Umur tanaman merupakan faktor yang menentukan kebutuhan air untuk pertanian dikarenakan pada setiap tahap kebutuhan airnya berbedabeda.Perbedaan ini disebabkan oleh tingkat kebutuhan air konsumtif (ETc) atau penguapan tanaman. Tingkat kebutuhan air konsumtif pada setiap umur yang berbeda-beda mempengaruhi total kebutuhan irigasi.

Pada masa tanam I tanaman padi rata-rata kebutuhan air konsumtif (ETc) untuk transpirasi tertinggi pada tahap permulaan atau padi pada umur 1-20 hari yakni sebesar $4,03 \mathrm{~mm} /$ dekade. Setelah tahap permulaan padi memasuki tahap perkembangan, tahap pertengahan, dan tahap akhir dimana kebutuhan air konsumtif (ETc) pada setiap tahapan selalu mengalami penurunan. Sedangkan rata-rata kebutuhan air konsumtif (ETc) terendah terdapat pada tahap akhir padi berumur 90 hari setelah masa tanam sampai masa panen $35,5 \mathrm{~mm} /$ decade.

Pada masa tanam II kebutuhan air konsumtif (ETc) tanaman jagung tertinggi terjadi pada tahap pertengahan pada saat jagung berumur 38-76 hari yakni sebesar 3,97 mm/hari. Kebutuhan air konsumtif (ETc) terendah di tahap permulaan pada saat jagung berumur 1-17 hari yakni sebesar $1,88 \mathrm{~mm} /$ hari.

Kebutuhan air konsumtif (ETc) tanaman jagung dimulai tahap permulaan sampai tahap pertengahan selalu mengalami peningkatan dan mencapai puncaknya pada tahap pertengahan.Setelah itu, pada akhir kebutuhan air konsumtif (ETc) mengalami penurunan.

Pada masa tanam III kebutuhan air konsumtif (ETc) tanaman jagung berbeda dengan MT II, hal ini disebabkan oleh tingkat penguapan berbeda antara pada bulan Maret 
sampai Juni dan Juli sampai Oktober.Akhir-akhir bulan merupakan masa kemarau dengan suhu tinggi dan lama penyinaran dalam sehari lebih banyak dibandingkan pada bulan-bulan lainnya.

Kebutuhan air konsumtif (ETc) masa tanam III tertinggi terjadi pada saat jagung memasuki tahap pertengahan dengan umur 38-76 hari yakni 4,28 $\mathrm{mm} /$ hari. Kebutuhan air konsumtif (ETc) terendah terjadi pada saat jagung berumur 1-17 hari yakni $2,01 \mathrm{~mm} /$ hari.

Tipe tanaman pada masa tanam yang sebagian besar diterapkan di Desa Nguter juga menentukan kebutuhan air untuk irigasi. Pada masa tanam I total kebutuhan air tanaman padi rata-rata dari seluruh jaringan irigasi di Desa Nguter sebesar 1.877.184,12 $\mathrm{m}^{3} / \mathrm{MT} / \mathrm{ha}$.

Pada masa tanam II total kebutuhan air tanaman jagung ratarata dari seluruh jaringan irigasi di Desa Nguter sebesar 1.519.776,9 $\mathrm{m}^{3} / \mathrm{MT} / \mathrm{ha}$, sedangkan pada masa tanam III total kebutuhan air tanaman jagung ratarata dari seluruh jaringan irigasi di Desa Nguter sebesar 1.582.157,6 m³/MT/ha.

Kebutuhan air konsumtif (ETc) padi lebih besar daripada jagung, karena padi sangat peka terhadap ketersediaan air dibandingkan tanaman jagung.Jadi, umur tanaman dan tipe tanaman menentukan jumlah kebutuhan air konsumtif (ETc) yang dibutuhkan untuk transpirasi tanaman.

\section{Penutup}

\section{Simpulan}

Berdasarkan hasil analisis dan pembahasan yang terdapat pada paparan diatas, dapat disimpulkan bahwa kualitas mata air Semeru yang diteliti tidak memiliki perubahan pada setiap musimnya, sehingga dapat dinyatakan sebagai air bersih dan sesuai untuk memenuhi kebutuhan penduduk dan irigasi. Jika dilihat dari kuantitas mata air Semeru pada musim penghujan 1.143,04 liter/menit dan pada musim kemarau sebesar 1.109,36 liter/menit. Sehingga kebutuhan air bersih sebesar 604.758 liter/hari dan 612.381 liter/hari dan kebutuhan air irigasi dapat terpenuhi dengan baik.

\section{Saran}

Berdasarkan hasil dan pembahasan dari penelitian ini maka dapat dirumuskan saran dan masukan. Adapun saran dalam penelitian ini adalah bagi pemerintah, penelitian ini dapat menjadi pijakan dalam pengelolaan dan pengembangan sumberdaya air. Penelitian ini juga dapat memberikan informasi tambahan bagi peneliti selanjutnya dan pembaca sebagai informasi tentang teknik pengembangan sumberdaya air untuk pemenuhan air bersih penduduk dan irigasi pertanian. Serta sebagai dasar melakukan pengembangan dibeberapa daerah yang masih belum mengoptimalkan sumber air.

\section{Daftar Pustaka}

Badan Pusat Statistik. 2015. Kabupaten Lumajang dalam angka 2015.

Effendi, Hefni. 2003. Telaah Kualitas Air (Bagi Pengelolaan Sumberdaya dan Lingkungan Perairan). Yogyakarta: Kanisius.

Fatchan dan Purwanto. 1990. Geografi

Pertanian. Buku Penunjang

Perkuliahan. Malang.

Perpustakaan UM. 
Kodoatie, R. 2012. Tata Ruang Air Tanah.Yogyakarta. Andi Offset.

Linsley.1995. Teknik Sumberdaya Air Jilid 2. Jakarta: Erlangga.

Suyono dan D, Darmakusuma. 1991. Evaluasi Sumberdaya Lahan (Hidrologi). Yogyakarta. Universitas Gadjah Mada.

Wardani, Anastasia Erista. 2010. Evaluasi Potensi Mata Air untuk Kebutuhan Air Domestik di Kecamatan Cangkringan Kabupaten Sleman Pasca Erupsi Merapi. Jurnal. Universitas Gadjah Mada.

Widayanti, Mustikowati. 2014. Analisis Faktor-faktor yang mempengaruhi Konsumsi Air Bersih Golongan Pelanggan Rumah Tangga III Wilayah Pelayanan Cabang Timur PDAM Kota Semarang. Skripsi. Universitas Diponegoro. 